\title{
Criação de lugar para o outro numa medicina de deslugar
}

Pe. José Nuno Ferreira da Silva*

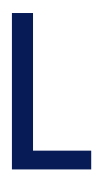
embro-me, em menino, dos médicos da Caixa. Vieram, depois, os clínicos gerais. Já de há anos para cá chegaram os Médicos de Família. Na designação dos primeiros, a percepção do povo - não sei se diga antes: dos pobres... - era a da vinculação dos médicos ao sistema a que pertenciam, a Caixa de Previdência, e não sei como se percebiam estes a si mesmos. Os segundos, os de Clínica Geral, eram percebidos e percebiam-se na sua vinculação a uma especialidade nova e surpreendente, nesse passado Portugal da década de 1980, uma especialidade em processo de criação e afirmação. Agora, criada e afirmada, a Clínica Geral veio encontrar e aprofundar a consciência da sua identidade nos Médicos de Família que, por este vínculo, são percebidos e se percebem, ou não, e o povo - principalmente os pobres, que sempre voltamos aos pobres! - às vezes queixa-se.

Hoje já não nos surpreendemos com a existência da rede de cuidados de saúde primários e a proclamação do direito de cada cidadão ao seu médico de família. Surpreendemo-nos, isso sim, com o facto de haver muitos que não têm médico de família e com a estranheza de algumas soluções propostas para resolver o problema, nomeadamente as que agridem a possibilidade real de o médico de família o ser.

Esta breve evocação da saga instituinte desta especialidade vem a propósito do título que me deram para este artigo da Revista Portuguesa de Medicina Geral e Familiar.Efectivamente, as coordenadas estruturantes desta especialidade são as da criação de lugar para o outro, no contexto de uma medicina muitas vezes deslugar.

Sendo-o ainda, o sistema de saúde português já foi mais hospitalocêntrico e a medicina hospitalar tende, pelos seus próprios dinamismos e pelos mecanismos institucionais, a ser uma medicina de deslugar. Dou já o exemplo para, depois, me fazer à explicação. Quando me encontro entre médicos, geralmente distingo os

*Capelão do Centro Hospitalar São João. da rede de cuidados de saúde primários dos da rede hospitalar antes de uns e outros se declararem. É que os segundos falam de episódios, os primeiros contam histórias, biografias mesmo. Eé aqui que se define a medicina como criação de lugar para o outro: a abertura à história do outro enquanto história de um outro. É certo que no hospital se colhem histórias clínicas para fazer diagnósticos. Mas na medicina familiar acompanham-se histórias de vida no seu acontecer e enquanto acontecem para nela desempenhar um papel definido como acompanhamento: as pessoas dizem "o meu médico" ou "o médico que me acompanha". A medicina geral e familiar é, por excelência, o campo onde a Medicina Narrativa ${ }^{1}$ mais deverá ser praticada.

Há alguns anos atrevi-me a propor o neologismo que agora me propuseram no título que me foi dado para esta reflexão: deslugar. ${ }^{2}$ Defini-o como instituição ou espaço destituído das características antropológicas e sociológicas do lugar para onde são transferidas experiências vitais que implicam sofrimento e insegurança identitária para a sociedade e para o indivíduo. Para chegar a esta definição socorri-me do contributo de reconhecidos autores dos âmbitos da antropologia e da sociologia. A Michel Foucault pedi o conceito de heterotopia, ${ }^{3}$ espaços à parte mas em relação com a sociedade, para onde se desviam experiências críticas. Em Marc Augét encontrei o não-lugar, espaços que não gozam das características do lugar antropológico, concretamente, não são nem identitários, nem relacionais, nem históricos, normalizando e anonimizando quem os frequenta. Foi Anthony Giddens quem ofereceu uma categoria particularmente relevante, a arena de sequestro, ${ }^{5}$ espaços marginais mas comunicantes para onde são segregadas as experiências existenciais perturbadoras e que muitas vezes são sistemas periciais apenas internamente referenciais.

Analisado na perspectiva do morrer como realidade para aí transposta, o hospital, e não apenas no que concerne à questão da morte, vive sobre a linha de risco que desenha o deslugar como, à luz das propostas dos au- 
tores referidos, se pode perceber. Não tem necessariamente que ser assim, nem sequer é necessariamente assim. Mas pode ser assim e, tendencialmente, é assim.

A medicina familiar, se fiel a si mesma, é intrinsecamente reactiva ao deslugar. A um olhar leigo, a história da medicina geral e familiar parece ser a da emancipação da medicina em relação ao hospital (tendencialmente deslugar) e o seu percurso ao encontro das pessoas no seu lugar, entendendo este não apenas em sentido geográfico ou administrativo, mas sobretudo em sentido antropológico e sociológico, o lugar a que pertencem com aquele sentido de pertença que plasma o ser e configura a existência.

A contínua referência ao hospital, ao longo destas linhas, se se deve à experiência que deste vive quem escreve, a verdade é que se deve muito mais à necessidade sentida de apelar a um paradigma para melhor compreender outro diferente, assim como para definir saúde termos que definir doença. Concretamente, para melhor compreendermos a medicina geral e familiar na sua característica especificante dentro da perspectiva desta reflexão, a proximidade, é útil olhar a medicina hospitalar, que é uma medicina institucionalizada exercida na distanciação à origem do paciente. Não o escrevo como quem deprecia, mas como quem procura analisar e tenta perceber realidades diferenciadas que na sua diferenciação mutuamente ajudam a entender cada uma a outra.

A medicina geral e familiar é - deveria ser! - a medicina de ao pé da porta, de dentro da porta, até, quando necessário, mais doméstica do que tão somente domiciliar. Só esta capta a pessoa no seu ser pessoa e a pessoa que é, porque só no seu lugar é que a pessoa é o que é e vive como tal. A vocação da medicina geral e familiar é percorrer a aproximação até que o médico de família seja realmente o médico da família e, enquanto tal, elemento integrante do lugar da pessoa porque a família é o primeiro da série de círculos sociais, concêntricos e interactuantes, alargando-se progressivamente, em que pessoa se realiza; a família é o primeiro e aquele em que a pessoa é quem é. O grau de aproximação a este núcleo central é que define a qualidade da medicina geral e familiar como medicina de proximidade. $O$ médico de família, não fazendo parte dela, toma no entanto parte na família, corre-lhe entre as mãos o fio (des)contínuo da vida da família. E afirmo-o livre do romantismo tão rústico quanto belo do velho João Semana.
Ao médico de família é dada a possibilidade de viver do modo mais inteiro a experiência em que radica a medicina: o encontro entre o médico e o doente como acontecimento simbólico, história partilhada, caminho percorrido a dois, em que cada um se oferece ao outro como lugar; o médico, lugar em que o doente mora pela confiança e pela entrega; o doente, lugar em que mora o médico pela consciência e pela competência. Sendo reciprocamente lugar, justifica-se sublinhar que o médico se recebe do doente que é quem o institui médico, confiando-se-lhe e, porque médico de família, confiando-se-lhe como membro de uma família.

Mais que um saber, a medicina é uma sabedoria e a medicina geral e familiar é porventura aquela que melhor o pode experimentar, porque mais próxima da fonte dela, o povo, o povo e as suas pertenças, o povo nos seus lugares. Aí mergulha a medicina geral e familiar e, quanto mais beber desta fonte, tanto mais será criação de lugar para o outro num tempo em que obediências de gestão e quimeras de poder ligadas a hipotecas tecno obrigam ou seduzem os médicos para a medicina de deslugar. A ser assim, então a medicina geral e familiar - a par da medicina paliativa, que aliás requer e a que oferece a rede de proximidade necessária à prestação de cuidados paliativos - é lugar de regeneração humanista e humanizadora da própria medicina.

É desafiante ser médico de família. Exige tanto de resistência como de projecto. E não valerá a pena resistir e projectar quando o que está em causa é a criação de lugar para o outro?

\section{REFERÊNCIAS BIBLIOGRÁFICAS}

1. Charon R. Narrative medicine: honoring the stories of illness. New York: Oxford University Press; 2008. ISBN 0195340221

2. Silva JN. A morte e o morrer entre o deslugar e o lugar: precedência da antropologia para uma ética da hospitalidade e cuidados paliativos. Porto: Afrontamento; 2012. ISBN 9789723612646

3. Foucault M. Des espaces autres. EMPAN. 2004;2(54):12-9. Available from: http://www.cairn.info/revue-empan-2004-2-page-12.htm

4. Augé M. Non-Lieux: introduction à une anthropologie de la surmodernité. Paris: Seuil; 1992. ISBN 9782020125260

5. Giddens A. Modernity and self-identity: self and society in the late Modern Age. Cambridge: Polity Press; 1991. ISBN 9780804719445

\section{CONFLITO DE INTERESSES}

O autor declara não ter conflitos de interesses.

ENDEREÇO PARA CORRESPONDÊNCIA

pjosenuno@med.up.pt 